\title{
REVERBERATION OF LEGAL PRINCIPLES: FURTHER THOUGHTS ON THE DEVELOPMENT OF AN EU PRINCIPLE OF PROHIBITION OF ABUSE OF LAW
}

Rita de la Feria

OXFORD UNIVERSITY CENTRE FOR BUSINESS TAXATION 


\title{
Reverberation of Legal Principles: Further Thoughts on the Development of an EU Principle of Prohibition of Abuse of Law
}

\author{
RITA DE LA FERIA*
}

This brief paper considers the ongoing debate over the development of an EU principle of probibition of abuse of law, offering some further thoughts on the topic. In particular, the paper reflects first on the role of the principle within the field of free movement of persons, in the context of the literature on convergences and divergences between the fundamental freedoms. It then progresses to propose the notion of reverberation as a new conceptual framework for the analysis of the development of general principles of EU law - in this case based upon the ongoing example of probibition of abuse of law. The paper concludes with some thoughts on the future of the principle of probibition of abuse of law and its potential consequences.

\section{THE RATIONALE: UNFINISHED PRINCIPLES}

On February 2006 the Court of Justice delivered its eagerly awaited ruling in Halifax, a case concerning the interpretation of EU secondary legislation on Value Added Tax (VAT). ${ }^{1}$ The judgment represented the culmination of a long process, with the Court referring for the first time to the 'principle of prohibiting abusive practices'.2

The Court had been alluding to abuse and abusive practices for more than thirty years, since its decision in Van Binsbergen on free movement of services. ${ }^{3}$ For a long time, however, the significance of these references was unclear. The terminology used by the Court was inconsistent, there were important outstanding questions regarding the

\footnotetext{
${ }^{*}$ I am extremely grateful to Conor O'Reilly for his insightful comments and suggestions throughout this project. Whilst we invariably comment on each other's work, the unusual length and complexity of this endeavour meant that his involvement was much more than what would reasonably have been expected. Any errors or omissions are of course my own.

${ }^{1}$ Case C-255/02 Halifax plc, Leeds Permanent Development Services Ltd, County Wide Property Investments Ltd v .Commissioners of Customs \& Excise [2006] ECR I-1609.

2 At para [70] of the ruling.

${ }^{3}$ Case 33/74 Jobannes Henricus Maria van Binsbergen v. Bestuur van de Bedriffsvereniging voor de Metaalnijverheid [1974] ECR 1299.
} 
applicability criteria, and little academic interest directed towards the topic. ${ }^{4}$ This state of affairs changed radically in the last decade, with the subject of abuse of law gaining significant prominence, primarily within tax law circles. Whilst this marked change has been attributed to a variety of factors, two successive events undoubtedly played major roles: the development of an abuse test by the Court in Emsland-Stärke in 2000; ${ }^{5}$ and the subsequent emergence of an intense debate as to whether the Court would apply this new test within the field of taxation. These events intensified the process, which had already been initiated, ultimately culminating with the ruling in Halifax.

Yet, Halifax also represented the beginning of a new process: the discussion, led almost exclusively by tax academics and practitioners, over the significance of the newly designated 'principle of prohibition of abuse of law'. Fundamental questions immediately arose and were the subject of intensive debate such as: the scope of application of the principle - would it apply to other areas of tax law, in particular to corporate taxation; the criteria for application of the principle - how would the abuse test set out by the Court in Halifax be applied; and, the nature and implications of this 'principle' - interpretative, general, or neither.

As a tax lawyer I had been accompanying - and indeed actively participating - in this discussion from the outset. As something of an imposter EU lawyer, however, I was also acutely aware of the comparatively scarce discussion of abuse of law outside the tax field. Some of the commentary written from a tax perspective often seemed to lack a wider context: very few were asking first, what was the EU law background to EmslandStärke and Halifax; second, and more importantly perhaps, what were the EU law consequences of those decisions from a broader perspective. In essence, there appeared to be a lack of intra-disciplinary dialogue: tax lawyers were not fully engaging with the EU law literature, principles or case law; and EU lawyers were (perhaps blissfully) unaware of the revolution that was taking place within EU tax, and how that could influence their particular field of research.

\footnotetext{
4 Notable exceptions were $\mathrm{N}$ Brown, 'Is there a general principle of abuse of rights in European Community Law?' in T Heukel and D Curtin (eds), Institutional Dynamics of European Integration, vol II, (Dordrecht, Martinus Nijhoff Publishers 1994) 511-525; A Kjellgren, 'On the Border of Abuse - The Jurisprudence of the European Court of Justice on circumvention, fraud and other misuses of Community Law' (2000) 11 European Business Law Review 179-194; and K Engsig Sørensen, 'Abuse of rights in Community law: A principle of substance or merely rhetoric?' (2006) 43 Common Market Law Review 423459.

${ }^{5}$ Case C-110/99 Emsland-Stärke GmbH v. Hauptzollamt Hamburg-Jonas [2000] ECR I-1569.
} 
With those concerns in mind, it seemed appropriate to initiate a process of retrospective analysis, re-tracing the Court's decisions prior to Emsland-Stärke, trying to understand how cases like Centros and Chen could have constituted the backdrop, ${ }^{6}$ or could be read in the context of, these new decisions within the taxation area. ${ }^{7}$ In this quest to understand precisely what was going on and to bring it together into what would hopefully be a coherent theoretical framework, two key objectives crystallized: first, to find order; and second, to spark intra-disciplinary awareness. The result was an article published in 2008 in the Common Market Law Review. ${ }^{8}$ In the process of writing that article, however, it further became evident that the surface of a much larger issue was being scratched. To truly shed light upon the topic of abuse of law, and to understand a process of development that had progressed almost imperceptibly for almost thirty years, an intradisciplinary debate, which brought together experts in tax law and EU law was required. It was in this context that the idea of convening such an academic symposium emerged.

After a year of preparations, a symposium was finally held at Oxford on October 3-4, 2008. Over the course of two intense days almost forty papers were presented by invited speakers from across Europe and further afield. Each bringing specialised knowledge in different areas of EU, comparative and tax law and all demonstrating remarkable commitment and patience. The structure followed in the resulting volume emulates that adopted in the symposium. ${ }^{9}$ The papers were divided into eight sessions, having been preceded by a keynote address by (the then) Advocate General Miguel Poiares Maduro. As the Advocate General in Halifax, he was the obvious choice to formally chair the event. Most would agree that more than merely influencing the Court's decision in that case, his Opinion provided its theoretical basis, establishing the foundations for the newly designated 'principle of prohibition of abuse of law'. Miguel Poiares Maduro's insightful introduction was followed by sessions, which are mirrored in the framework of the volume's contents.

\footnotetext{
${ }^{6}$ Cases C-212/97 Centros Ltd v Erbvervs- og Selskabsstyrelsen [1999] ECR I-1459, and C-200/02 Kunqian Catherine Zhu, Man Lavette Chen v Secretary of State for the Home Department [2004] ECR I-9925.

7 The ruling in Halifax was just the turning point; soon after the Court delivered its decisions in Cadbury Schweppes and Kofoed, both cases applying the newly designated principle of prohibition of abuse of law to the field of corporate taxation, see cases C-196/04 Cadbury Schweppes plc, Cadbury Schweppes Overseas Ltd v Commissioners of Inland Revenue [2006] ECR I-7995, and C-321/05 Hans Markus Kofoed v Skatteministeriet [2007] I-5795.

${ }^{8} \mathrm{R}$ de la Feria, 'Prohibition of Abuse of (Community) Law: The Creation of a New General Principle of EC Law through Tax’ (2008) 45 Common Market Law Review 395.

${ }^{9} \mathrm{R}$ de la Feria and S Vogenauer (eds), Prohibition of Abuse of Lasw - A New General Principle of EU Law? (Oxford, Hart Publishing, 2011).
} 
Section II ('The Framework') of the volume focuses upon questions such as: the notion, source and effects of general principles of EU law (Arnull); the origins of the concept of 'abuse of rights' in civil law (Gordley); on whether abuse of law can indeed be regarded as a general principle of law (Farmer, Engsig Sørensen); and, whether it matters what kind of principle it is (Engsig Sørensen). In Section III ('The Origins') we moved towards more detailed analysis of the concept of abuse of law, particularly in the context of the free movement provisions. The following issues, amongst others, are addressed: how the concept of abuse of rights was initially used in the Court's decisions (Weatherill); the contribution of the Court's decisions in advertising cases to the development of a notion of abuse of law (Doukas); how the concept fits into the model of the law of the free movement (Weatherill); and how, moving away from a pure fundamental freedoms analysis, the concept can also be looked at from a labour law perspective (Barnard). Section IV ('The Development') concentrates on the company law related matters, tackling thorny subjects, such as: the impact of the Court's decision in Centros in both the concept of abuse of law, ${ }^{10}$ and company law activity (Ringe); the significance of the ruling in Cadbury Schweppes for the Centros line of case-law, ${ }^{11}$ and for regulatory competition in general (Vella); the concept of abuse of law in the context of secondary legislation on insolvency, the choice of applicable insolvency regime (Eidenmüller), and the abusive shift of the debtor's 'centre of main interest' (Armour); the relevance of abuse of law in the context of financial and investment services (Tridimas), and the impact of the concept on the Directive on Markets in Financial Instruments (Schammo). ${ }^{12}$ Section V ('The Test') concentrates on free movement of goods and the development of an abuse test in Emsland-Stärke. ${ }^{13}$ In this section the road to Emsland-Stärke is discussed, as well as the challenges presented by the abstract level of the test proposed therein, and the (non)application of the test by national courts and by the Court of Justice itself in other cases (Koutrakos, Snell).

In Sections VI and VII of the volume we enter murkier conceptual waters, where the relevance of the notion of abuse of law is either unknown or disputed. Section VI ('The Unknown') presents different perspectives as regards the impact which abuse of law has,

\footnotetext{
${ }^{10}$ Case C-212/97 Centros Ltd v. Erhverus- og Selskabsstyrelsen [1999] ECR I-1459.

${ }^{11}$ Case C-196/04 Cadbury Schweppes plc, Cadbury Schweppes Overseas Ltd v. Commissioners of Inland Revenue [2006] ECR I-7995.

12 Directive 2004/39/EC of the European Parliament and of the Council of 21 April 2004 on markets in financial instruments (MiFID) amending Council Directives 85/611/EEC and 93/6/EEC and Directive 2000/12/EC of the European Parliament and of the Council and repealing Council Directive 93/22/EEC [2004] OJ L145/1.

${ }^{13}$ Case C-110/99 Emsland-Stärke GmbH v Hauptzollamt Hamburg-Jonas [2000] ECR I-1569.
} 
or has not had, within private law and international civil procedure: analysis of why the principle of abuse of law has not entered the private law scene (Metzger), as well as a warning to the constitutional dangers of recognising the relevance of such a principle in EU private law or EU contract law (Whittaker), are presented; and, discussion of how the doctrine of abuse of law has had a discrete influence on the development of international civil procedure (Cuniberti), as opposed to being rejected (Briggs), is also undertaken. The positions expressed in Section VII ('The Exception') are more uniform: full rejection of the impact of the concept of abuse of law within the field of free movement of workers (Ziegler, Spaventa) and citizenship (Costello, Dougan) is almost unanimous, with one sole exception (Faull).

In Section VIII ('The Confirmation') attention shifted to the area which had triggered recent interest in the topic of abuse of law: taxation. Several topics are addressed in this section, in particular the following: the impact of nationally developed approaches to tackle tax avoidance in Court of Justice's decisions, and the impact of those decisions in national courts and systems (Freedman, Lang); whether there is one legal concept of abuse of law, or different concepts applicable to different areas of EU law, or even of tax law, namely direct and indirect taxation (Pistone, Vanistendael, Lyal), or corporate and personal taxation (Dourado); whether abuse of law takes place, or is applicable, at different levels (Weber, Gosh, Dourado); the relevance of the subjective element of the abuse of law test when applied to tax cases (Weber, Lang); whether a principle of prohibition of abuse should also apply to institutions, and not only to economic operators (Lyons); the background and impact of the Court's decision in Halifax for VAT (Pistone, Vanistendael, Lyal), and in Cadbury Schweppes for corporate tax (Vanistendael, Lang, Gosh); the application of the concept of abuse of law in the context of personal taxation (Dourado, Simpson); and the (ir)relevance of the abuse of law to the field of state aid (Lyons, Quigley). The volume finishes in Section IX ('Conclusion') with Vogenauer's analysis of the different views expressed across these various chapters on the new 'principle of prohibition of abuse of law'.

It is impossible to do justice in this brief paper to the wealth of knowledge and insight displayed in all of these contributions. Nevertheless, a few overall points stand out which - based on an admittedly subjective assessment - merit preliminary comments. Furthermore, the richness of the discussion held at the symposium, together with the indepth analysis present in the chapters, sparked further reflection on a number of specific aspects of the discussion, resulting in some additional personal thoughts on the matter. 


\section{HIERARCHY OF FREEDOMS: ALL FREEDOMS ARE FUNDAMENTAL, BUT...}

When reading the various chapters in the volume, it becomes evident that insofar as abuse of law is concerned there are significant differences across freedoms, and particularly between free movement of persons and other fundamental freedoms. Of the chapters focussing on free movement of persons, only one seems to accept in principle the relevance of prohibition of abuse of law to that freedom, although acknowledging the Court's somewhat indifference to the concept within that field $;{ }^{14}$ all others reject the relevance of the concept to free movement of persons and citizenship rights. ${ }^{15}$ More interestingly perhaps, whilst rejecting the relevance of the concept to that field, some authors specifically acknowledge their relevance to other freedoms, or to corporate law. ${ }^{16}$ It is indeed undeniable that the Court has demonstrated a very different approach to abuse claims within the field of workers and citizenship, to that displayed as regards all other freedoms. ${ }^{17}$ It is also true that traditionally there has been a dichotomy between the Court's interpretation of the provisions on free movement of persons and of those concerning other freedoms. ${ }^{18}$ Moreover, such a dichotomy has often been defended and justified on the basis that economic transactions and human beings should indeed be treated differently, and / or that workers should be regarded as having a higher moral value. $^{19}$ Yet, there has also been a feeling that the Court has in more recent times

\footnotetext{
${ }^{14}$ See J Faull, "Prohibition of Abuse of Law": A New General Principle of EU Law', ch 20 in de la Feria and Vogenauer (n 9 above).

15 See K Ziegler, “Abuse of Law” in the Context of the Free Movement of Workers', ch 21 in de la Feria and Vogenauer (n 9 above); E Spaventa, 'Comments on Abuse of Law and the Free Movement of Workers', ch 22 in de la Feria and Vogenauer (n 9 above); C Costello 'Citizenship of the Union: Above Abuse?', ch 23 in de la Feria and Vogenauer (n 9 above); and M Dougan, 'Some Comments on the Idea of a General Principle of Union Law Prohibiting Abuses of Law in the Field of Free Movement for Union Citizens', ch 24 in de la Feria and Vogenauer (n 9 above).

${ }^{16}$ Spaventa comments that 'the category of abuse of law is factually irrelevant in this field [free movement of workers]'; however 'a principle of abuse of law might be particularly relevant in relation to corporate tax law' (n 15 above); similarly Costello (n 15 above).

${ }^{17}$ See as paradigmatic example Case C-200/02 Kunqian Catherine Zhu, Man Lavette Chen v Secretary of State for the Home Department [2004] ECR I-9925; see also my comments in de la Feria (n 8 above).

${ }^{18} \mathrm{~J}$ Snell comments that 'the Court has consistently favoured the movement of Union citizens over other forms of free movement', see 'And Then There Were Two: Products and Citizens in Community Law' in T Tridimas and P Nebia (eds), European Union Law for the Twenty-First Century (Oxford, Hart Publishing 2004) 41-68, at 62. There is extensive literature on what is generally known as convergences and divergences between the freedoms; in addition to the references cited above and below see also: M Poiares Maduro, 'Harmony and Dissonance in Free Movement' and HD Jarass 'A Unified Approach to the Fundamental Freedoms' in M Andenas and WH Roth (eds), Services and Free Movement in EU Law (Oxford University Press, 2002) 41-68 and 141-162 respectively.

${ }^{19}$ See P Oliver and WH Roth. 'The Internal Market and the Four Freedoms' (2004) 41 Common Market Law Review 407; and C Banard, 'Fitting the Remaining Pieces into the Goods and Persons Jigsaw?' (2001) 26 European Law Review 35; see also Advocate General Fennelly in Case C-190/98 Volker Graf v Filzmoser Maschinenbau GmbH [2000] ECR I-493, para [18].
} 
displayed a desire to achieve convergence between the freedoms. ${ }^{20}$ Whether there is full convergence, however, is not fundamental for the debate on prohibition of abuse of law: indeed, one can easily envisage a situation where the Court - perhaps justifiably - does not apply the principle for the purposes of judicial review uniformly across all areas of EU law, and the intensity of judicial review exercised varies depending on the subject matter. ${ }^{21}$ What is considerably more difficult to envisage, or accept, is the application of a principle to all fundamental freedoms - and more recently to other areas outside free movement - with the exception of free movement of persons. It seems, therefore, more appropriate to accept the application of the principle of prohibition of abuse of law to all areas of EU law, without exception, whilst acknowledging that in some of these areas, and namely free movement of workers and Union citizens, abuse of law will be harder to find. This approach appears to find some judicial support: apart from more formal references by the Court to abuse of law, the principle was applied to significant extent and detail by Advocate General Poiares Maduro in Conæilio Nationale degli Ingegneri to the 'general system governing mutual recognition of diplomas', which falls within the scope of free movement of persons. ${ }^{22}$ Whilst the Court did not address the matter of abuse of law in its judgment, the Opinion of the Advocate General stands out as an indication of a possible route to apply the principle of prohibition of abuse of law in a coherent, if not necessarily uniform manner, to all areas of EU law.

\section{REVERBERATION OF LEGAL PRINCIPLES: ON THE ORIGIN (AND DEVELOPMENT) OF PRINCIPLES}

Formulating general principles of EU law has been characterised as the result of a dialectical interaction between national laws and EU law; both the outcome and the

\footnotetext{
${ }_{20}$ Advocate General Poiares Maduro stated in 2006 that 'such an harmonisation of the system of free movement seems to me to be essential in the light of the requirements of genuine Union citizenship. It would be desirable for the same system to be applied to all the citizens of the Union wishing to use their freedom of movement or freedom to move services, goods or capital as well as their freedom to reside or to set up their seat of their activities in the Community', see Joined Cases C-158/04 and C-159/04 Alfa Vita Vassilopoulos AE, formerly Trofo Super-Markets AE (C-158/04), and Carrefour Marinopoulos AE (C159/04) v Elliniko Dimosio, Nomarkbiaki Aftodiikisi Ioanninon [2006] ECR I-8135, para [51]. See also A Trytonidou, 'Further steps on the road to convergence among the market freedoms' (2010) 35 European Law Review 1, 36-56.

${ }^{21}$ The 'sliding scale of judicial review' is a phenomenon well-known within constitutional law literature, see D Doukas, Werbefreibeit und Werbebeschränkungen: Eine europa- und grundrechtliche Untersuchung der Kontrollmaßstäbe für Beschränkungen der kommerziellen Kommunikation, dargestellt am EG-Recht, an der EMRK, am deutschen Grundgesetz. und an der griechischen Verfassung (Baden-Baden, Nomos 2005).

22 Case C-311/06 Consiglio Nazionale degli Ingegneri v Ministero della Giustizia, Marco Cavallera (CNDI) [2009] ECR I-415, paras [43] et seq. Interestingly only one of the chapters in the volume makes reference to this case, and even then not one concerning on free movement of persons, but rather taxation, see D Weber 'Abuse of Law in the Context of Indirect Taxation: Comments', ch 27 in de la Feria and Vogenauer (n 9 above).
} 
source of a long process of cross-fertilisation, back and forth, between the national legal orders and the EU legal order. ${ }^{23}$ Words usually applied in the context of the extensive literature on diffusion of law, such as 're-transplantation' and 'reception', ${ }^{24}$ have been employed in association with the whole or part of this dynamic process $-{ }^{25}$ and justifiably so. Diffusion of law, generally considered to take place when one legal order, system or tradition influences another in a significant way, ${ }^{26}$ is indeed a useful concept when looking at the process of creation and development of EU legal principles. Whilst what constitutes 'influence' is notoriously difficult to determine, it seems clear that the legal pluralism, which characterises the relationship between the EU legal order and the legal orders of the Member States, ${ }^{27}$ implies by its own nature diffusion of law in a broad sense. Particularly useful in this regard is the so-called cross-level diffusion: the idea that diffusion takes place not as a direct one-way transfer between two legal systems, but multi-laterally across different levels of ordering; that it may occur between many kinds of legal orders and across different geographical levels. ${ }^{28}$ Yet, none of these terms or concepts is completely successful in describing comprehensively and accurately either the way EU law interacts with national laws in general, or the dynamic process of creation and development of general principles of EU law in particular.

A term that has not been used so far, either within the context of general principles of EU law, or more generally in the literature of diffusion of law, is that of 'reverberation'. ${ }^{29}$ Nevertheless, as a concept that expresses both the idea of acoustics and that of wave, it

\footnotetext{
${ }^{23}$ See W van Gerven, 'Two Twin-Principles of EU Law: Democracy and Accountability, Consistency and Convergence' in U Bernitz, J Nergelius and C Cardner (eds), General Principles of EC Law in a Process of Development (Alphen aan den Rijn, Wolters Kluwer 2008) 28-29.

${ }^{24}$ As highlighted by W Twining the study of diffusion of law has proceeded under many labels, including reception, transplants, spread, expansion, transfer, exports and imports, imposition, circulation, transmigration, transposition and transfrontier mobility of law, see 'Diffusion of Law: A Global Perspective' (2005) 49 Journal of Legal Pluralism 1; on the use of these various expressions see also D Nelken 'Towards a Sociology of Legal Adaptation' in J Feest and D Nelken, Adapting Legal Cultures (Oxford, Hart Publishing 2001) 3.

${ }^{25}$ See respectively G de Búrca, 'Proportionality and subsidiarity as general principles of law' in Bernitz, Nergelius and Cardner (eds) (n 23 above) 95; J Usher, 'The Reception of General Principles of Community Law in the United Kingdom' (2005) 16 European Business Law Review 489.

${ }^{26}$ See Twining (n 24 above).

27 On the sources and challenges of the European legal pluralism, see M Poiares Maduro, 'Interpreting European Law - Judicial Adjudication in a Context of Constitutional Pluralism' (2008) Working Papers IE Law School, WPLS08-02.

${ }^{28}$ See Twining (n 24 above).

29 The term has been used in relation to European affairs, but within another context: within the literature on so-called Europeanisation and multi-level governance within the EU, as reverberation of European policy within national arenas, see V Mörth, 'Europeanization as Interpretation, Translation and Editing of Public Policies' in K Featherstone and CM Radaelli (eds), The Politics of Europeanization (Oxford, Oxford University Press 2003), 159-178; and CM Radaelli, 'The Europeanization of Public Policy' in K Featherstone and CM Radaelli (eds), The Politics of Europeanization (Oxford, Oxford University Press 2003) 27-56.
} 
has perhaps the potential to describe the richness of that dynamic process of creation and development of principles: as sound, progressively spreading throughout the EU and the national legal orders; and as a wave, bouncing back and forth, both between the EU judicial arm and the courts and legislatures of the Member States (vertically), and between courts and legislatures of different Member States amongst themselves (horizontally).

Applying the concept of reverberation to the process of creation and the development of general principles of EU law in particular, this can be distilled into three stages: precognisance, cognisance and post-cognisance. The process starts at pre-cognisance level with similar principles or legal concepts applied within different Member States' jurisdictions not necessarily all - being cast into the centre of questions referred to the Court of Justice. Often these principles or concepts are similar only to the extent that at their core they express an identical legal essence, even though its particular characteristics, such as scope and criteria for application and name or designation, differ from Member State to Member State. This vagueness which results from the discrepancies between Member States, also gives the Court a higher level of flexibility to use the concept in whatever context it feels more appropriate, providing it with a specific scope and criteria for application, definition, etc. ${ }^{30}$ The concept or principle is then on the path to becoming an EU legal principle or concept, ${ }^{31}$ used in different judgments, reiterated and added-to, without full awareness of its significance, scope or meaning. Realisation of the process of creation of a new principle of EU law is now unavoidable, with cognisance being not necessarily triggered internally within the Court of Justice itself, but often externally, either by national courts or legal commentators - or normally by both. Once made aware of the process in due course the Court has to decide on whether to proceed or not thus, whilst the process involves various agents, the Court is in essence the sole cognisance-agent.

Post-cognisance, the intensity of the dialectic debate will significantly increase, with the interaction also becoming more focussed: the Court of Justice will tend to frame its

\footnotetext{
${ }^{30} \mathrm{It}$ is precisely this freedom of the Court to create principles which has given rise to strong criticism, more recently in the context of the Court's decision in Mangold (Case C-144/04 Werner Mangold v Rüdiger Helm [2005] ECR I-9981); see M Herdegen, 'General Principles of EU Law: The Methodological Challenge' in Bernitz, Nergelius and Cardner (eds) (n 23 above) 343-355; Ziegler (n 15 above); Dougan (n 15above).

31 As TC Hartley points out 'whatever the factual origin of the principle, it is applied by the European Court as a principle of Community law, not national law', see The Foundations of European Community Law, 5th ed. (OUP, 2003) 134; see also A Arnull, 'What is a General Principle of EU Law?', ch 2 in de la Feria and Vogenauer (n 9 above).
} 
decisions differently, imposing a new structure in light of the new legal principle; whilst national courts' requests for preliminary rulings will also become more specific and targeted around the principle. ${ }^{32}$ As the new principle develops legal commentators focus their attention more closely on the topic and national legislatures may also react by imposing new rules which better reflect - or respect - the new principle of EU law. At this stage the dialectic process is no longer solely vertical, but also horizontal, with national courts and even legislatures responding both to doctrinal and jurisprudential developments in other Member States. ${ }^{33}$ Table 1 provides an illustration of the reverberation process through its different stages.

\footnotetext{
32 For a recent commentary on this collaboration and mutual deference between the Court of Justice and national courts, see CF Sabel and O Gerstenberg, 'Constitutionalising an Overlapping Consensus: The ECJ and the Emergence of a Coordinate Constitutional Order' (2010) 16 European Law Journal 511.

33 As J Usher notes 'What is undeniable is that in purely domestic legal situations, courts in the United Kingdom can be found making express reference to decisions of, and principles developed by, the European Court of Justice, and to legal literature written by academics from other Member States', in 'General Principles and National Law - A Continuing Two-Way Process' in Bernitz, Nergelius and Cardner (eds) (n 23 above) 393, 415.
} 
Phase I: Pre-Cognisance

Court of Justice

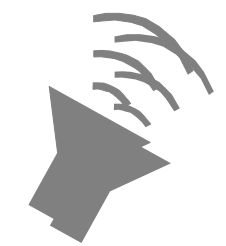

National Courts / Legislatures

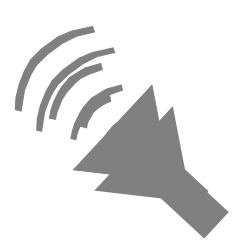

National Courts / Legislatures

Phase II: From Pre-Cognisance to Cognisance

Court of Justice

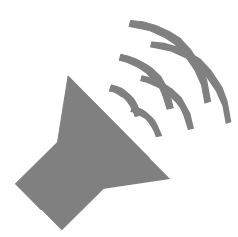

National Courts / Legislatures

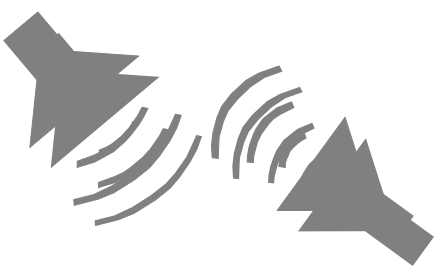

National Courts / Legislatures

\section{Phase III: From Cognisance to Post-Cognisance}

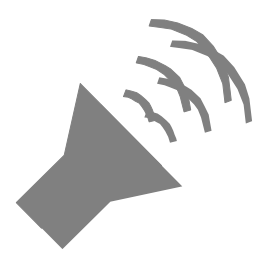

National Courts / Legislatures
Court of Justice
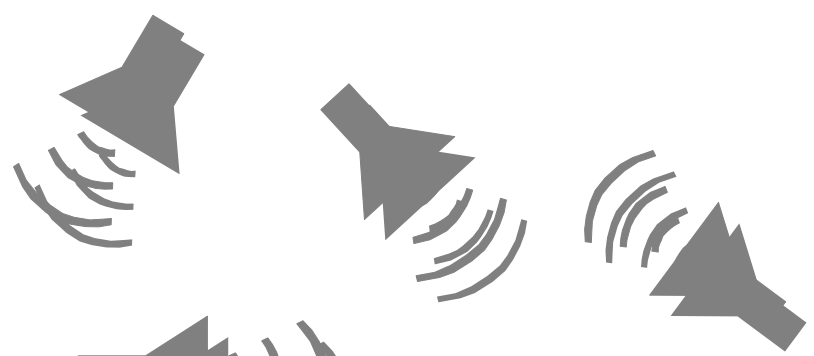

National Courts / Legislatures

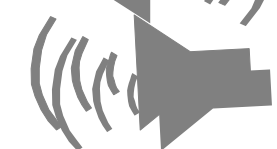

This process of reverberation in its different stages can be observed as regards the creation and development of the principle of prohibition of abuse of law. The precognisance stage can be said to extend from the first references by the Court to abuse and 
abusive practices in Van Binesbergen in the 1970s, to the ruling in Halifax in 2006. ${ }^{34}$ During this period, the Court made consistent reference to prohibition of abuse and abusive practices in response to questions referred to it by national courts. ${ }^{35}$ Similar to other principles and legal concepts, the concept of abuse was present within the legal systems of many Member States, but its particular characteristics, such as the scope and criteria for application and designation, differed from Member State to Member State. ${ }^{36}$ The vagueness resulting from these discrepancies gave the Court of Justice the freedom to slowly and progressively develop - via the dialectic process between the Court of Justice and the national courts - a new EU concept of abuse, with a specific meaning, scope and criteria for application.

After almost thirty years, the passage from dormant status to full consciousness, from pre-cognisance to cognisance, finally came with Halifax. Engulfed in an intense stream of legal commentary, the reference by the London VAT and Duties Tribunal arrived to the Court of Justice in 2002. It turned out to be the first of several referrals, which arrived to the Court between 2002 and 2004, on the application of, what was designated then by the national referring courts as the doctrine or principle of abuse of rights, to VAT. ${ }^{37}$ The delay in providing a definite answer in any of these cases was in itself indicative of the Court's transition to a cognisance stage in the process of creating a new legal principle. $^{38}$ Following a landmark Opinion by Advocate-General Poiares Maduro, the Court finally delivered its decision in Halifax in 2006, in which it confirmed the existence of a principle of prohibition of abuse of law that applied to the sphere of VAT.

Since the decision in Halifax - immediately followed by those in Cadbury Schweppes and Kofoed on direct taxation $-{ }^{39}$ we have entered the post-cognisance period, with vertical interaction between the EU judicial arm and the courts and legislatures of the Member

\footnotetext{
${ }^{34}$ Case 33/74 Johannes Henricus Maria van Binsbergen v Bestuur van de Bedrijfsvereniging voor de Metaalnijverheid, [1974] ECR 1299; and Case C-255/02 Halifax plc, Leeds Permanent Development Services Ltd, County Wide Property Investments Ltd v Commissioners of Customs \& Excise [2006] ECR I-1609.

${ }^{35}$ For an overview of this period see de la Feria. (n 8 above).

36 As noted by J Freedman, 'The Anatomy of Tax Avoidance Counteraction: Abuse of Law in a Tax Context at Member State and European Union Level', ch 25 in de la Feria and Vogenauer (n 9 above).

37 Case C-419/02 BUPA Hospitals Ltd, Goldsborough Developments Ltd v Commissioners of Customs \& Excise [2006] ECR I-1685; Case C-223/03 University of Huddersfield Higher Education Corporation v Commissioners of Customs \& Excise [2006] ECR I-1751; Case C-452/03 Chancery Division RAL (Channel Islands) Ltd and Others v Commissioners of Customs and Excise [2005] ECR I-3947; Case C-63/04 Centralan Property Ltd v Commissioners of Customs \& Excise [2005] ECR I-11087.

${ }^{38}$ In both RAL and Centralan the Court avoided answering the questions on abuse of law (n 37 above); whilst the decisions in Halifax, BUPA and University of Huddersfield were significantly delayed. The joint Opinion by Advocate-General Poiares Maduro was delayed by two months (initially due in February 2005, it was in fact only released in April 2005); and Halifax and BUPA were the last VAT-related cases (by several months), entering the Court's register in 2002, to be ruled upon.

${ }^{39}$ See n 36 above.
} 
States, and horizontal interaction between courts and legislatures of different Member States amongst themselves, intensifying. ${ }^{40}$ National legislation of various Member States has been altered as a result of the Court's rulings on abuse of law, and national courts have started to apply the EU concept of abuse to purely internal situations. This has appears to have been the case in France, ${ }^{41}$ Italy, ${ }^{42}$ Ireland, ${ }^{43}$ Netherlands, ${ }^{44}$ and the UK. ${ }^{45}$ In addition various new cases have been referred to the Court of Justice specifically concerning the application of the new principle of prohibition of abuse of law, as set out in Halifax. In this regard UK and Italian courts seem to have been particularly active: in 2007 the Court issued its ruling in Part Service, a case originating from the Italian courts; ${ }^{46}$ more recently Opinions have been issued in two UK cases by Advocate-General Mazák in Weald Leasing and RBS Deutschland Holdings; ${ }^{47}$ and another Italian case is currently pending before the Court, 3MItalia. ${ }^{48}$ Whilst many of these cases concern tax, it is interesting to note the range of European law areas in which the Halifax ruling and the principle of prohibition of abuse of law has been invoked: contractual liability; ${ }^{49}$ free movement of workers and recognition of professional qualifications; ${ }^{50}$ freedom of establishment and company law; ${ }^{51}$ social policy ${ }^{52}$ competition $;{ }^{53}$ common customs

\footnotetext{
${ }^{40}$ As J Freedman comments 'the traffic is not one-way but multi-directional' (n 36 above).

${ }^{41}$ See L Leclercq, 'Interacting principles: The French abuse of law concept and the EU notion of abusive practices' (2007) Bulletin for International Taxation, 235-244; S de Monès et al, 'Abuse of Tax Law Across Europe (Part One)' (2010) 2 EC Tax Review 85; and Freedman (n 36 above).

${ }^{42}$ See C Garbarino, 'The Development of a Judicial Anti-Abuse Principle in Italy' (2009) 2 British Tax Review 186; S de Monès et al, 'Abuse of Tax Law Across Europe (Part Two)' (2010) 3 EC Tax Review 123; and Freedman (n 36 above).

${ }^{43}$ See T Lyons 'State Aid, Taxation and Abuse of Law', ch 34 in de la Feria and Vogenauer (n 9 above).

${ }^{44}$ See Case C-352/08 Modehuis A Zwijnenburg BV v Staatssecretaris van Financiën, Judgment of 20 May 2010, nyr; and Freedman (n 36 above).

${ }^{45}$ See R de la Feria, 'HMRC $v$ Weald Leasing Ltd. Not only artificial: The abuse of law test in VAT' (2008) 5 British Tax Review 556-563; the very recent decision of the UK Upper Tribunal in Commissioners of Her Majesty's Revenue and Customs v Moorbury Limited, FTC/21/2009, 16 September 2010; and Freedman (n 36 above).

${ }^{46}$ Case C-425/06 Ministero dell'Economia e delle Finanze v Part Service Srl [2008] ECR I-897.

${ }^{47}$ Case C-103/09 The Commissioners for Her Majesty's Revenue \& Customs v Weald Leasing Limited, Opinion of 26 October 2010, nyr; and Case C-277/09 The Commissioners for Her Majesty's Revenue \& Customs v RBS Deutschland Holdings GmbH, Opinion of 30 September 2010, nyr.

${ }^{48}$ Case C-417/10 Ministero dell'Economia e delle Finanze; Agenzia delle Entrate v 3 M Italia SpA [2010] OJ C288/23.

${ }^{49}$ Case T-271/04 Citymo SA v Commission [2007] ECR II-1375; discussed in Lyons (n 43 above).

${ }^{50}$ Case C-311/06 Consiglio Nazionale degli Ingegneri v Ministero della Giustizia, Marco Cavallera (CNDI) [2009] ECR I-415; discussed in Weber (n 22 above).

${ }^{51}$ Case C-210/06 Cartesio Oktató és Szolgáltató bt [2008] ECR I-9641. This case has given rise to significant controversy and is discussed in several chapters below, namely: Arnull (n 31 above); S Weatherill 'Fitting 'Abuse of Rights' into EU Law Governing the Free Movement of Goods and Services', ch 5 in de la Feria and Vogenauer (n 9 above); D Doukas 'Free Movement of Broadcasting Services and Abuse of Law', ch 6 in de la Feria and Vogenauer (n 9 above); WG Ringe 'Sparking Regulatory Competition in European Company Law: The Impact of the Centros Line of Case Law and its Concept of 'Abuse of Law", ch 8 in de la Feria and Vogenauer (n 9 above); J Vella 'Sparking Regulatory Competition in European Company Law: A Response', ch 9 in de la Feria and Vogenauer (n 9 above); H Eidenmüller 'Abuse of Law in the Context of European Insolvency Law', ch 10 below; J Armour 'Abuse of European Insolvency Law? A Discussion'
} 
tariff; ${ }^{54}$ and agricultural policy. ${ }^{55}$ Even more interestingly perhaps, the Halifax ruling and the principle of prohibition of abuse of law have also been invoked within the area of freedom, security and justice, ${ }^{56}$ and in a case concerning external relations where the principle was invoked by the UK Government and its applicability implicitly accepted by the Court, even though the case on the claim of abuse of law was rejected. ${ }^{57}$ As the principle of prohibition of abuse of law is increasingly invoked across a greater diversity of contexts, the process of reverberation, in its post-cognisance stage, continues - with the signal getting stronger, rather than weaker.

\section{CONCLUSION: PLAYING PINBALL WITH LEGAL PRINCIPLES}

In the context of the edited volume's wide-ranging contributions, ${ }^{58}$ one cannot help but wonder where this process of reverberation will ultimately lead: will the principle of prohibition of abuse of law continue to bounce back and forth until such time as it emerges as a fully-fledged general principle of EU law, or will it fall off the agenda destined to have a potential that is never realised, but sporadically echoes across the doctrine and jurisprudence of EU law? It is, of course, impossible to know for certain; however, the intensification and varied subjects affected by this reverberation process since cognisance indicate that the former is a more likely outcome. This leads to a final question, namely whether this is a positive, or a negative, development. Often the debate over the existence or non-existence of a general principle of prohibition of abuse of law has centred on the consequences of such a principle, with polarised views being displayed regarding the advantages or disadvantages of recognising its existence. Whilst

ch 11 in de la Feria and Vogenauer (n 9 above); T Tridimas 'Abuse of Rights in EU Law: Some Reflections with Particular Reference to Financial Law', ch 12 in de la Feria and Vogenauer (n 9 above); P Schammo 'Comments on Abuse of Rights in EU Law', ch 13 in de la Feria and Vogenauer (n 9 above); J Snell 'The Notion of and a General Test for Abuse of Rights: Some Normative Reflections', ch 15 in de la Feria and Vogenauer (n 9 above); Costello (n 15 above); M Lang 'Cadbury Schweppes' Line of Case Law from the Member States' Perspective', ch 30 in de la Feria and Vogenauer (n 9 above); AP Dourado 'A Single Principle of Abuse in European Union Law: A Methodological Approach to Rejecting a Different Concept of Abuse in Personal Taxation', ch 32 in de la Feria and Vogenauer (n 9 above); and Lyons (n 43 above). For an interesting discussion of the impact of this case in previous case-law on abuse in company law, see A Frada de Sousa 'Company's Cross-border Transfer of Seat in the EU after Cartesio' (2009) Jean Monnet Working Papers $7 / 09$.

52 Case C-396/07 Mirja Juuri v Fazer Amica Oy [2008] ECR I-8883.

${ }^{53}$ Case C-260/07 Pedro IV Servicios SL v Total España SA [2009] ECR I-2437.

${ }^{54}$ Case C-7/08 Har V aessen Douane Service BV v Staatssecretaris van Financiën [2009] ECR I-5581.

55 Case C-434/08 Arnold und Johann Harms als Gesellschaft bürgerlichen Rechts v Freerk Heidinga, Judgment of 20 May 2010, nyr.

${ }^{56}$ Case C-168/08 Laszlo Hadadi (Hadady) v Csilla Marta Mesko, married name Hadadi (Hadady) [2009] ECR I6871; discussed in J Snell (n 51 above).

${ }^{57}$ Case C-16/05 R (on the application of Veli Tum and Mehmet Dari) v Secretary of State for the Home Department (SSHD) [2007] ECR I-7415; discussed in KE Sørensen 'What is a General Principle of EU Law? A Response', ch 3 in de la Feria and Vogenauer (n 9 above), and Costello (n 15 above).

${ }^{58}$ See $n 9$ above. 
interconnected, these are however theoretically separate questions. Since publication of my article in 2008 , there would seem to be an assumption that a quest to determine the significance of the Court's references to abuse of law, and to establish whether they amounted to the establishment of a general principle of EU law, implies advocacy of such a development. ${ }^{59}$ This cannot be further from the truth. Similar to the reservations expressed by some commentators about the jurisprudential process of creation of general principles of EU law, ${ }^{60} \mathrm{I}$ too have expressed some concerns over the creation of a principle of prohibition of abuse of law. Initially coming from a VAT perspective, these were essentially two-fold: ${ }^{61}$ first, that the introduction of a principle, which was in essence a powerful tool against tax avoidance, would deter Member States from adopting legislative measures that targeted the causes of tax avoidance rather than its manifestations; ${ }^{6}$ second, and more importantly, that the introduction of such a principle would significantly encroach upon the principle of legal certainty, which requires that 'rules imposing charges on the taxpayer must be clear and precise so that he may know without ambiguity what are his rights and obligations'. ${ }^{63}$ Ultimately, however, the lack of awareness of the process that creates a principle has the potential to be much more detrimental to the principle of legal certainty, than the principle of abuse of law itself. Regardless of the consequences, it must be recognised that cognisance is fundamental to minimising legal uncertainty - or in other words, 'it is better the devil [or principle] you know than the one you don't.'

\footnotetext{
${ }^{59}$ See in particular Cussens \& Ors v Brosnan [2008] IEHC 169 (Irish High Court).

${ }^{60}$ See M Herdegen (n 30 above) 344; and Opinion of Advocate-General Mazák in Case C-354/04 P Gestoras Pro Amnistía, Juan Mari Olano Olano and Julen Zelarain Errastiv Council of the European Union [2007] ECR I-1579.

${ }^{61}$ The arguments are developed further in R de la Feria, 'The European Court of Justice's Solution to Aggressive VAT Planning-Further Towards Legal Uncertainty?' (2006) 1 EC Tax Review 27.

${ }^{62}$ Advocate General Poiares Maduro has presented a similar argument as regards anti-tax fraud measures: 'The United Kingdom seems to envisage combating carousel fraud - or at least dispensing with the problems it poses - by limiting the scope of the VAT system. To my mind, the Court should not consent to this approach. It would drastically shift the burden of the problem from the tax authorities to the private sector, at the expense of legitimate trade and the proper functioning of the VAT system. Moreover, it would deter Member States from taking appropriate measures against carousel fraud', see Joined Cases C354/03, C-355/03 and C-484/03 Optigen Ltd (C-354/03), Fulcrum Electronics Ltd (C-355/03) and Bond House Systems Ltd (C-484/03) v Commissioners of Customs \& Excise [2006] ECR I-48, para [43].

${ }^{63}$ Case 169/80 Administration des douanes v Société anonyme Gondrand Frères and Société anonyme Garancini [1981] ECR 1931.
} 


\section{Oxford University Centre for Business \\ TAXATION \\ Working PAPER SERIES}

WP10/20 Haufler, Andreas and Frank Stähler Tax competition in a simple model with heterogeneous firms: How larger markets reduce profit taxes

WP10/19 Cnossen, Sijbren Improving the VAT Treatment of Exempt Immovable Property in the European Union

WP10/18 Grubert, Harry and Richard Krever VAT and Financial Supplies: What should be taxed?

WP10/17 Gendron, Pierre-Pascal, VAT Treatment of Public Sector Bodies: The Canadian Model

WP10/16 Niepmann, Friederike and Tim Schmidt-Eisenlohr, Bank Bailouts, International Linkages and Cooperation

WP10/15 Bond, Stephen and Jing Xing, Corporate taxation and capital accumulation

WP10/14 Lockwood, Ben, How should financial intermediation services be taxed?

WP10/13 Becker, Johannes, Fuest, Clemens and Nadine Riedel, Corporate tax effects on the quality and quantity of FDI

WP10/12 Fuest, Clemens and Nadine Riedel, Tax Evasion and Tax Avoidance in Developing Countries: The Role of International Profit Shifting

WP10/11 Wildasin, David E., State Corporation Income Taxation: An Economic Perspective on Nexus

WP10/10 Becker, Johannes and Marco Runkel, Corporate tax regime and international allocation of ownership

WP10/09 Simpson, Helen, How do firms' outward FDI strategies relate to their activity at home? Empirical evidence for the UK

WP10/08 Voget, Johannes, Headquarter Relocations and International Taxation

WP10/07 Devereux, Michael P. and Simon Loretz, Evaluating Neutrality Properties of Corporate Tax Reforms 
WP10/06 Davies, Ronald B. and Lourenço S. Paz, Tariffs Versus VAT in the Presence of Heterogeneous Firms and an Informal Sector

WP10/05 Finke, Katharina, Heckemeyer, Jost H., Reister Timo and Christoph Spengel, Impact of Tax Rate Cut Cum Base Broadening Reforms on Heterogeneous Firms - Learning from the German Tax Reform 2008

WP10/04 Koh, Hyun-Ju and Nadine Riedel, Do Governments Tax Agglomeration Rents?

WP10/03 Dischinger, Matthias and Nadine Riedel, The Role of Headquarters in Multinational Profit Shifting Strategies

WP10/02 Vrijburg, Hendrik and Ruud A. de Mooij, Enhanced Cooperation in an asymmetric model of Tax Competition

WP10/01 Bettendorf, Leon, van der Horst, Albert, de Mooij, Ruud A. and Hendrik Vrijburg, Corporate tax consolidation and enhanced cooperation in the European Union

WP09/32 Bettendorf, Leon, Devereux, Michael P., van der Horst, Albert, Loretz, Simon and Ruud A. de Mooij, Corporate tax harmonization in the EU

WP09/31 Karkinsky, Tom and Nadine Riedel, Corporate Taxation and the Choice of Patent Location within Multinational Firms

WP09/30 Becker, Johannes and Clemens Fuest, Transfer Pricing Policy and the Intensity of Tax Rate Competition

WP09/29 de la Feria, Rita, VAT and the EC Internal Market: The Shortcomings of Harmonisation

WP09/28 Damjanovic, Tatiana and David Ulph, Tax Progressivity, Income Distribution and Tax Non-Compliance

WP09/27 Grubert, Harry, MNC Dividends, Tax Holidays and the Burden of the Repatriation Tax: Recent Evidence

WP09/26 Grubert, Harry, Foreign Taxes, Domestic Income, and the Jump in the Share of Multinational Company Income Abroad

WP09/25 Maffini, Giorgia, Tax Haven Activities and the Tax Liabilities of Multinational Groups

WP09/24 Bach,Laurent and Nicolas Serrano-Velarde, The Power of Dynastic Commitment

WP09/23 Dischinger, Matthias and Nadine Riedel, There's No Place Like Home: The Profitability Gap between Headquarters and their Foreign Subsidiaries 